\title{
Bailout Clauses and the Price of Credit: The Dutch Experience for Housing Corporations
}

\author{
Jacob Veenstra ${ }^{1}\left(\right.$ B $\cdot$ Bernard van Ommeren $^{2}$
}

Published online: 18 April 2017

(C) The Author(s) 2017. This article is an open access publication

\begin{abstract}
The bulk of capital provided to Dutch housing corporations is explicitly guaranteed by a bailout clause. Using a dataset with loans provided by the largest Dutch public sector bank (BNG Bank), we find substantial evidence that this bailout clause has reduced interest rates by about 72 basis points. The annual benefits of reduced interest costs outweigh the costs of default. We also find that the interest rates for guaranteed loans are insensitive to the financial position of corporations. We therefore surmise that the bank relied on the bailout clause. Finally, the bailout clause for corporations (which guarantees individual loans) and the one for municipalities (which entirely protects municipalities from defaulting) lead to a similar reduction in interest.
\end{abstract}

Keywords Bailout · Guarantees · Housing corporations · Interest spreads ·

Bank loans

JEL Classification E43 - G21 · H81

\section{Introduction}

The Dutch (semi-)public sector is well-known for its explicit bailout clauses (or guarantees). The presence of a bailout clause means that if an organisation would run into

Electronic supplementary material The online version of this article (doi:10.1007/s10645-017-9299-2) contains supplementary material, which is available to authorized users.

Jacob Veenstra

jacob.veenstra@rug.nl

Bernard van Ommeren

bernard.vanommeren@bngbank.nl

1 Faculty of Economics and Business, and Centre for Research on Local Government Economics, University of Groningen, PO Box 800, 9700 AV Groningen, The Netherlands

2 BNG Bank, PO Box 30305, 2500 GH The Hague, The Netherlands 
trouble, it will receive financial assistance from its counterparts or from the government. The idea behind this is to communicate to creditors that providing capital entails no risk. This should reduce interest rates on loans so that more resources can be devoted to the public goal. A major advantage of a guarantee (in contrast to for example a subsidy) is that it does not have to cost society any money if it proves to be sustainable.

In many countries, however, bailouts are explicitly ruled out by legislation. This is to prevent 'moral hazard'; the danger that debtors become less rigorous in controlling their finances knowing that they would be assisted should problems arise (Rodden 2006). Debtors thus face a 'soft budget constraint' (Kornai et al. 2003), which is seen to encourage them to behave irresponsibly. Thus in the literature, the dominant view is that an explicit no-bailout clause must be formulated in order to emphatically state to institutions that they will not be rescued (Allers 2015). In practice, however, it is difficult to credibly enforce such a clause. Actual bankruptcy of subnational governments or (semi-)public organisations could entail high welfare and political costs (Goodspeed 2002; Plekhanov and Singh 2007). Indeed, there are numerous examples of bailouts actually occurring despite the existence of a no-bailout clause (Rodden 2006; Heppke-Falk and Wolff 2008). However, in the Dutch public sector explicit and regulated guarantees exist for, e.g., housing corporations, health care institutions and municipalities. In the case of municipalities, Allers (2015) notes that the bailout clause has not led to excessive malpractice. Therefore, he argues, there is sufficient reason to challenge the traditional view that bailouts must be ruled out. It may even be the case that the benefits of a bailout clause (reduced interest payments) outweigh the costs (defaults on loans and/or increased inefficiencies). This paper attempts to measure the effect of a bailout clause on interest rates by focusing on loans made to (housing) corporations.

Firstly, by comparing a set of guaranteed and unguaranteed corporation loans, we investigate whether the bailout clause succeeds in lowering interest rates. Secondly, we study whether differences in interest rates can be explained by corporation characteristics such as indebtedness; under a credible bailout clause all corporations should pay the same interest rate on similar loans, regardless of their financial position. Thirdly, we investigate whether the design of the bailout clause is relevant for interest payments by comparing the guarantee system of corporations (which secures individual loans) with that of municipalities (whose entire financial position is secured).

Existing literature mostly focuses on no-bailout or implicit bailout clauses (for an overview, see van Hecke et al. 2012). To our knowledge, this paper is the first study investigating the effect of an explicit bailout clause. We exploit a unique micro-level dataset of loans made to housing corporations that distinguishes both guaranteed and unguaranteed loans. This enables us to investigate whether structural differences exist between the two groups of loans.

The rest of this paper is set up as follows. Section 2 describes the institutional background of housing corporations, paying special attention to the bailout agreements. Section 3 briefly outlines the theory on interest rate determination and provides hypotheses. In Sect. 4 we present the research set-up and in Sect. 5 the data. Section 6 delivers our main results. The robustness of our findings is tested in a sensitivity analysis presented in Sect. 7. Section 8 offers our conclusions. 


\section{Institutional Background}

\subsection{Housing Corporations}

The social housing market in the Netherlands is dominated by housing corporations; privately governed institutions executing a set of public tasks. In 2014, the 363 Dutch housing corporations possessed a total of around 2.4 million dwellings, which equals about $30 \%$ of the total housing stock (source: Statistics Netherlands). From an international viewpoint, these figures are remarkably large (Whitehead and Scanlon 2007). The total value of debt in the sector amounted to more than 90 billion euro (source: CorpoData). Interest payments were approximately 4 billion euro in 2014 (an average of about 1700 euro per dwelling).

About half of the corporations' external funding is obtained from BNG Bank, the largest public sector bank in the Netherlands. Corporations can also fund themselves through NWB Bank (the second largest public sector bank) or, alternatively, through commercial banks. Public sector banks benefit from high credit ratings and therefore low funding costs. This is reinforced by the likelihood of government support as a result of their public policy mandate (Birry et al. 2013). In the literature, this support could be assessed as an implicit subsidy causing market distortions. Those who benefit from the implicit subsidy have a competitive advantage over those that do not (Noss and Sowerbutts 2012).

Until the end of the twentieth century, the Dutch central government actively intervened in the social housing market by providing, for example, project subsidies. Over the past decades however, the ties between government and corporations have loosened, both financially and operationally. In the 1990s subsidies were eliminated. To compensate, the central government relieved corporations of a substantial part of their debt. The other major advantage that housing corporations enjoy is a system of loan guarantees.

\subsection{The Guarantee Scheme for the Social Housing Sector}

A credible no-bailout clause serves to make creditors aware of the risks of a loan (i.e., the probability of default). Higher credit risk translates into higher interest rates. As debtors aim for the lowest possible interest rate, they have an incentive to closely manage their financial positioning. In the Dutch case, where bailouts are explicitly regulated, this 'market discipline' is absent or at least distorted (Lemmen 1999; Schuknecht et al. 2009).

However, a form of 'rule discipline' does exist in the Netherlands, in the form of legislation and policies that constrain institutions' borrowing capacity in practice (Lemmen 1999; Schuknecht et al. 2009). The Guarantee Fund Social Housing (Waarborgfonds Sociale Woningbouw, WSW) assesses each corporation's financial position in order to determine whether or not it may borrow under the guarantee of the bailout clause (WSW 2009). These WSW-guarantees are thus not unconditional. If the WSW considers creditworthiness insufficient and, if there are no visible signs of improvement, it may refuse the granting of guarantees. 
Dutch housing corporations access two main types of loans; guaranteed and unguaranteed. Only capital used for investing in the service of general economic interest (Diensten van Algemeen Economisch Belang, DAEB), such as building dwellings for low-income households, can be guaranteed. In contrast, loans financing, for example, commercial activities, are not guaranteed. Also, short-term loans (defined here as having a maturity of less than 2 years) are never guaranteed.

The guarantee scheme consists of three levels. First, if the resources of a housing corporation are insufficient to resolve its own problems, 'reorganisation subsidies' may be provided by the financial supervisor, the Central Public Housing Fund (Centraal Fonds Volkshuisvesting, CFV). ${ }^{1}$ These subsidies are paid for by implementing a 'oneoff tax' on other housing corporations.

At the second level, creditors can appeal to the guarantee funds of the WSW if the reorganisation subsidies are insufficient. The WSW has a financial reserve that can be called upon and if this reserve drops below a certain threshold, it can increase its resources by enforcing a contribution from all housing corporations. This contribution is calculated on the basis of outstanding guaranteed debt of each corporation. At the end of 2014, the sum total of WSW-guarantees was approximately 3.5 billion euro (source: Ministry of the Interior and Kingdom Relations 2016).

In essence, these first two levels of the guarantee scheme boil down to mutual support among corporations. There is a further third level, however: if necessary, the government will step in to provide interest-free loans to the WSW. The burden of debt thus entailed is then equally divided between central government and municipalities.

De Jong (2013) concludes that the complexity of this scheme provides weak incentives for creditors to monitor corporations, and will lead to excessive risk for the sector as a whole. Indeed, a few (large) corporations did get into severe financial distress in the past decades. However, despite these incidents, until now only the first level of the guarantee scheme has ever been accessed. Thus, so far, the bailout clause is proving to be sustainable. From 31 December, 1990 until 2014, just 21 corporations received reorganisation subsidies to a total of about 1.5 billion euro (in euros of 2014) (source: CFV 2015, own calculations). Therefore, if interest savings are large enough, it is not unimaginable that the benefits of the bailout clause outweigh the costs.

\section{Theory and Hypotheses}

\subsection{Interest Rate Setting}

Suppose a party (e.g., a housing corporation) borrows from a bank. If the bank is certain that the loan will be recovered, it will be satisfied with the risk-free interest rate. Suppose now, that the creditor faces a positive probability $P\left(X_{j}\right)$ that debtor $j$ will default on the loan, where $X_{j}$ is a vector of variables affecting this probability. Assuming risk-neutrality, the bank is only willing to make the loan if the expected return $\left(R_{i, j}^{\text {exp }}\right)$ at least equals the risk-free return $\left(R^{f}\right)$, or:

\footnotetext{
1 Since July 1, 2015, the CFV has been replaced by the Authority Housing Corporations (Autoriteit woningcorporaties, Aw) and decisions concerning reorganisation subsidies are being made by the WSW since then.
} 


$$
\begin{aligned}
R_{i, j}^{\text {exp }} & =\left(1-P\left(X_{j}\right)\right) R_{i, j}+\tau_{i, j} P\left(X_{j}\right) R_{i, j}-P\left(X_{j}\right) c \geq R^{f} \\
i & =1,2, \ldots, N_{j}, j=1,2, \ldots, J
\end{aligned}
$$

where $R_{i, j}$ is the rate of return agreed upon by the creditor and debtor $j(j=1,2, \ldots, J)$ on loan $i\left(i=1,2, \ldots, N_{j}\right)$. Note that $R_{i, j}=1+r_{i, j}$, where $r_{i, j}$ is the interest rate of the loan. Further, $\tau_{i, j}$ is the proportion of the return that the creditor recovers in case of default, following Heppke-Falk and Wolff (2008). We extend Heppke-Falk and Wolff's (2008) model by including a variable $c$ that denotes the extra costs that would not be recovered in case of default, such as legal costs or delays in payment (Schulz and Wolff 2009). ${ }^{2}$

Solving (1) for $R_{i, j}$ yields:

$$
R_{i, j} \geq \frac{R^{f}+P\left(X_{j}\right) c}{1-\left(1-\tau_{i, j}\right) P\left(X_{j}\right)}
$$

It can be seen from Eq. (2) that the required rate of return is increasing in $P\left(X_{j}\right)$ and $c$, and decreasing in $\tau_{i, j}$.

Two benchmark scenarios emerge from Eq. (2) resembling the housing corporations' situation. If there is no bailout clause $\left(\tau_{i, j}=0\right)$, as would be the case for unguaranteed corporation loans, the minimally required return obtains its maximum value of:

$$
R_{i, j} \geq \frac{R^{f}+P\left(X_{j}\right) c}{1-P\left(X_{j}\right)}
$$

On the other hand, if there is an explicit bailout clause that guarantees the loan $\left(\tau_{i, j}=\right.$ 1 ), the creditor may only require a premium above the risk-free rate in order to account for the non-recoverable costs, that is:

$$
R_{i, j} \geq R^{f}+P\left(X_{j}\right) c
$$

Finally, note the inequality sign in the equations. If we assume perfect competition, the actual return rate agreed upon $\left(R_{i, j}\right)$ equals the required rate of return, because if the creditor demanded a higher rate, the corporation would borrow from another bank. However, if the creditor has market power, it may obtain an extra premium (i.e., a commercial margin), which may depend on e.g., bargaining skills of both parties and the availability of alternative financing options.

In short, a positive interest spread (i.e., $R_{i, j}-R^{f}>0$ ) may occur because: (1) the loan is not guaranteed and there is a positive probability of default; (2) non-recoverable costs are relevant; or (3) the creditor succeeds in obtaining a commercial margin.

\footnotetext{
2 To be more complete, the total extra costs may be both fixed (legal costs) and/or dependent on the loan sum (payment delays). Total extra costs would then be $C=c *$ loan sum $+\bar{C}$. To get the return on the initial investment, this term should be divided by the loan sum (C/loan sum $=c+\bar{C}$ /loan sum $)$. For simplicity, Sect. 3.1 assumes that fixed costs $(\bar{C})$ are not relevant so that only $c$ appears in Eq. (1). Still, in the empirical part, the loan sum is included in the regressions.
} 


\subsection{Hypotheses}

As noted, our dataset allows us to distinguish between guaranteed and unguaranteed (mostly short-term) corporation loans. This offers us the unique opportunity to see what a bailout clause does to interest spreads.

According to Eq. (3), interest spreads are lower for guaranteed loans than for unguaranteed loans. Hypothesis 1 tests whether BNG Bank does indeed distinguish between the two types. Several authors have posited educated guesses about the effect of the bailout clause on interest rates: see van der Schaar (2006), Finance Ideas (2011), Hendriks (2013) and WSW (2014). Expected interest advantages lie between 0.5 and $1.5 \%$ points (or 50-150 basis points). However, firm empirical evidence is lacking.

Hypothesis 1 Unguaranteed loans have higher interest spreads than guaranteed loans.

For unguaranteed loans, corporation characteristics $\left(X_{j}\right)$ are presumed to be relevant determinants of the interest spread (see Eq. 3a). For guaranteed loans, according to Eq. (3b), these characteristics are only relevant if extra non-recoverable costs $(c)$ matter. If these costs are negligible, the interest spread may become insensitive to the risk profile of the corporation. Hypothesis 2 tests whether the relationship between corporation characteristics and interest spreads is different for guaranteed and unguaranteed loans.

Hypothesis 2 For unguaranteed loans, housing corporation characteristics influence the interest spread. For guaranteed loans, this relationship is weaker or even absent.

Van Hecke et al. (2012) provide an extensive overview of the literature on (the determinants of) interest spreads as far as local governments are concerned. The bulk of that literature concludes that higher debt leads to higher interest rates: see for example Booth et al. (2007), Landon and Smith (2007) and Heppke-Falk and Wolff (2008). Some of the literature holds that local government budget balance is also important (Booth et al. 2007; Schuknecht et al. 2009).

Most studies focus on countries where no (explicit) bailout clause exists. However, Heppke-Falk and Wolff (2008) focus on the German case in which a bailout of a region (Land) might well occur. The probability of a bailout could actually be predicted by a variable that the German law courts use in their assessments of bailouts. It appears that, indeed, the expectation of bailout payments lowers the interest rate. This suggests that investors do, in effect, take into account the possibility of a potential bailout.

Nevertheless, Heppke-Falk and Wolff (2008) find that as fiscal variables do have a significant influence on interest spreads, investors do not see regional governments as completely risk-free. This finding is not replicated by Schulz and Wolff (2009), however, who find that the effect of the debt level is only weakly significant.

Feld et al. (2013) focus on the case of Swiss cantons where there was a structural break in investors' expectations of potential bailout. In July 2003, the Swiss Federal Court officially decided that Valais canton was not obliged to bail out the municipality of Leukerbad after it came into financial trouble. Previous to this decision, Swiss law had indicated that although cantons did not have bailout obligations, they could still deviate from this ruling. This possibility apparently led to a widespread belief among 
investors that municipalities would be bailed out, if and when necessary. Indeed, Feld et al. (2013) find that, cantons, being relieved from any expected bailout obligations, have seen a decline in bond yields by 25 basis points since the 2003 judgment.

The Swiss case shows certain similarities with the situation of Dutch housing corporations, as both deal with two different bailout clauses. However, in the Swiss case, a distinction is made between a non-credible and a credible no-bailout clause, whereas the Dutch situation features an explicit bailout clause and an implicit no-bailout clause. Also, there was a cut-off between the two Swiss schemes in 2003, whereas in the case of Dutch corporations, both schemes coexist over the years.

In addition to financial characteristics, the scale of organisations can also be influential. Under a no-bailout clause very large organisations may be deemed 'too big to fail' meaning that for these organisations, the no-bailout clause would not be credible (Heppke-Falk and Wolff 2008). Also, one may assume that large institutions have more financial expertise and so they would bargain more effectively.

Finally, according to Eq. (3b), even in the presence of a bailout clause, interest rates may exceed risk-free rates due to non-recoverable costs. If these costs are relevant, even guaranteed loans would not be considered completely risk-free. Hypothesis 3 tests whether non-recoverable costs are of relevance, by comparing the interest spreads of housing corporation loans with those of municipality loans. The bailout clause for municipalities entirely protects them from defaulting, whereas for corporations, only individual loans are guaranteed. Thus, for municipalities the creditor is not involved in the process of recovering a loan in case of default and, therefore, there is no need to worry about non-recoverable costs. For housing corporations, on the other hand, the creditor is directly involved in the execution of the clause and, therefore, it is likely that $c$ is non-zero for corporations. Therefore, housing corporations may be charged higher interest rates than municipalities.

Hypothesis 3 The interest spreads on guaranteed housing corporation loans exceed the interest spreads on municipality loans.

\section{Research Set-Up}

To test Hypotheses 1 and 2, we estimate the following regression model:

$$
r_{i, j, t}^{\text {spread }}=\alpha+\beta \tau_{i, j, t}+\gamma X_{j, t}+\delta L_{i, j, t}+\theta_{t}+\mu_{j}+\varepsilon_{i, j, t}
$$

where $r_{i, j, t}^{\text {spread }}$ is the interest spread between a corporation loan and its risk-free reference rate. Thus:

$$
r_{i, j, t}^{\text {spread }}=r_{i, j, t}^{c}-r_{i, t}^{f}
$$

For each observation, a reference rate is used that has the same: (1) amortisation scheme; (2) contracting date; and (3) maturity. This way, we control for factors influencing the general interest rates in the economy, such as (expected) inflation, as well as structural differences in interest as a result of differences in amortisation or maturity. Opting for a spread frees us from the problem of explicitly controlling for these factors (Küttel and Kugler 2002). Note that we construct an interest spread in absolute, rather 
than relative terms. This is done because BNG Bank maintains that credit assessments lead to an additional spread in percentage points for risky loans, regardless of whether the risk-free interest rates in the economy are high or low. ${ }^{3}$ In our sensitivity analysis (Sect. 7), we use a relative spread as well.

Further, $\tau_{i, j, t}$ is a bailout indicator, taking the value of 1 if the loan is guaranteed (i.e., the loan belongs to the treatment group) and 0 if not (the control group), $X_{j, t}$ is a column-vector with corporation specific characteristics, $L_{i, j, t}$ denotes a columnvector with loan characteristics, $\theta_{t}$ is a year dummy, $\mu_{j}$ is a corporation specific (fixed) effect and $\varepsilon_{i, j, t}$ is the error term. $i$ is the loan subscript $\left(i=1,2,3, \ldots, N_{j}\right), j$ the corporation subscript $(j=1,2,3, \ldots, J)$ and $t$ the time subscript.

Note that the nature of our data may frustrate the estimation of the effect of a treatment (i.e., a bailout) since the treatment and control groups are dissimilar. Indeed, all short-term loans (with a maturity less than 2 years) are unguaranteed, whereas nearly all long-term loans are guaranteed. This may make identification problematic. That is, the effect of a bailout cannot be isolated completely, since the bailout indicator correlates with loan type (see Sect. 5.1) and maturity. If loan type or maturity is a relevant determinant of interest spreads, it is hard to isolate the effect of the bailout. Thus, the question is: to what extent is the interest spread influenced by the term structure and to what extent by the bailout clause? To deal with this, we first of all note that in principle, loan type and maturity should have no effect on interest spreads since our reference rates take these factors into account (see Sect. 5.2).

For completeness however, we will investigate the term structure of the interest spreads by means of regression discontinuity design (Thistlethwaite and Campbell 1960; Lee and Lemieux 2010). The idea behind this is that the relationship between maturity and interest spread has a discontinuity at a maturity of 2 years (because beyond this threshold, we deal with guaranteed loans). That is, at a maturity of 2 years or longer, we expect a sharp fall in interest spreads.

Additionally, note that there are also three unguaranteed bullet loans (11 when including inter- and extrapolation; see Sect. 7). Although this is a small number, for these loans, the effect of the bailout can be isolated.

Note also that we deal with clustered data, i.e., the data on individual loans is regressed on $X_{j, t}$, which are variables measured at a higher (housing corporation) level (Moulton 1990). We thus have $J$ clusters with $N_{j}$ observations. This could be a reason to cluster the standard errors at the level of housing corporations. However, because the clusters are unbalanced, this may lead to a downward bias in cluster robust standard errors (Rogers 1993; Nichols and Schaffer 2007). We use clustered standard errors in our main results and non-clustered errors in the sensitivity analysis (see Sect. 7).

Finally, to test Hypothesis 3, we estimate:

$$
r_{i, j, t}^{\text {spread }}=\alpha+\delta L_{i, j, t}+\varphi \text { Corporation dummy }{ }_{i, j, t}+\theta_{t}+\varepsilon_{i, j, t}
$$

where $r^{\text {spread }}$ is defined as in Eq. (4b), with the only difference that we do not only consider housing corporation loans $\left(r^{c}\right)$ but municipality loans $\left(r^{m}\right)$ as well. According to Hypothesis 3, we expect $\varphi>0$.

\footnotetext{
${ }^{3}$ Source: interview with the Chair of the Credit Committee of BNG Bank.
} 


\section{Data}

\subsection{Data Sources}

We have obtained micro-data on several financial products that BNG Bank provided to housing corporations between 1997 and 2013. We focus on four categories of products with a fixed interest rate and an amortisation scheme in line with available reference interest rates:

1. Short-term loans (maturity less than 2 years), where the principal is paid back at maturity.

2. Long-term loans where the principal is paid back at maturity (fixed or bullet).

3. Long-term loans where amortisation and interest is paid in equal instalments (annuity).

4. Long-term loans where the principal is paid back in equal instalments (linear).

These loan categories comprise 3440 loans (6835 when including inter- and extrapolation) and encompass $87 \%$ of the total loan sum of housing corporations borrowed from BNG Bank over our research period. Accurate reference rates are not currently available for other loan types. As noted, nearly all long-term loans (about 99.5\%) are guaranteed. Short-term loans on the other hand are, by definition, unguaranteed. In principle, the dataset comprises loans from 1997 until 2013, but for short-term loans there are no entries previous to 2008 as BNG Bank's internal system only maintains expired entries for limited periods. Also, corporation specific variables are available for 2001-2012 (annual data), obtained through CorpoData; the database of the CFV. This means that for Hypotheses 1 and 2, we cannot use all loans in the dataset. Finally, we have a similar data set with 4207 municipality loans (5514 when including inter- and extrapolation). ${ }^{4}$

\subsection{Reference Interest Rates}

We have linked every housing corporation loan to a reference interest rate given by BNG Bank. Before the start of every business day, the bank builds a 'pricing yield curve' by first connecting the funding interest rates of different maturities, and then adding surcharges for profit and costs (which may depend on loan sum and maturity), a liquidity premium if applicable, and a surcharge for cost of capital ('usage of balance sheet'). ${ }^{5}$ The lending yields represent 'norm prices' for risk-free lending which we use as our reference rates. The risk-free reference rates are published by BNG Bank on a daily basis to provide an indication to debtors about actual interest rate levels. ${ }^{6}$

However, for very short-term borrowing (maturity up to 1 month), the published reference rates are not meant for actual lending but fixed at a much higher level to discourage debtors to make use of these loans. Very short-term borrowing is labour

\footnotetext{
4 Note that we exclude short-term municipality loans, since it does not make sense to compare these with short-term corporation loans, since the latter are unguaranteed.

5 The BNG reference rates comprise all relevant components, including liquidity premiums if applicable. These liquidity premiums are not applicable to short-term loans, because the money market didn't ask for.

6 Note that these rates are only available for clients of BNG Bank.
} 
intensive and hardly profitable, so BNG Bank prefers that clients choose for a current account credit (which works automatically). In this case, actual lending is done at the Euribor level rather than at the published rate. ${ }^{7}$ Therefore, we use the Euribor rate as a reference for very short-term loans. In our sensitivity analysis (Sect. 7), we repeat the analysis while removing these loans.

Reference rates are available on a daily basis but not for all maturities. More specifically, we have reference rates for short-term loans with 1,2,3,6 and 12-month maturity, for bullet loans with 5 and 10-year maturity, for annuity loans with 10, 15, 20 and 25year maturity and for linear loans with 5, 10, 15, 20 and 25-year maturity. For other maturities, (linear) inter- and extrapolation could be used to obtain references. Because we have no reason to believe that the true yield curve is linear, this may lead to imprecise estimates. ${ }^{8}$ Therefore, in our main results we have excluded inter- and extrapolation. In the sensitivity analysis, we have included these observations (see Sect. 7).

Note that reference rates cannot precisely control for all loan characteristics, especially (1) the difference between the contracting and starting date of a loan and (2) the loan sum. Therefore these characteristics are included in the regression. For completeness, we also include the maturity of the loan. ${ }^{9}$

The reference rates are all based on relatively small loans (with loan sums up to 2.5 million euros). Because banking costs of a loan agreement are fixed to a large extent, a higher premium is demanded for small loans to cover costs. Therefore, the reference rates are relatively high and may therefore be considered to be upper estimates. ${ }^{10}$

\subsection{Independent Variables}

A brief description of the independent variables $\left(X_{i, j}, L_{i, j}\right.$ and $\left.\tau_{i, j}\right)$ is given below.

- Variables at housing corporation level (measured per dwelling):

- Company value is the net present value of future revenues and costs, estimated by the corporations themselves.

- Long-term debt gives the size of long-term debt.

- Equity is a refined measure of equity which takes into account future prospects of the corporation (CFV 2012). Equity is important for corporations as the financial supervisor uses this figure to judge corporation performance.

- Expected equity in $t+5$ gives the level of equity that the corporation expects to have in 5 years from the current year.

- Net cash flow gives the net cash flows resulting from operational activities.

- The number of dwellings is an indicator of the scale level.

\footnotetext{
7 Source: head of the Treasury department/client desk of BNG Bank.

8 For example, if the true yield curve is concave, this would mean that we underestimate reference rates.

9 Some loans have a fixed interest period that is shorter than the total maturity of the loan. In this case, the reference rate is based on this fixed interest period, since after that period, the interest rate may change. In the regressions however, we include the total maturity of the loan as a potential explanatory variable. Replacing this by the interest fixed period does not change results (details not shown).

10 BNG Bank does this to create a margin of safety in case interest rates would increase during the day. Source: interview with the manager of the client desk of BNG Bank.
} 
- Variables at individual loan level:

- Rating BNG measures the rating score that BNG Bank assigns to the riskiness of the loan, on a scale of 1 (expected probability of default of $0.01 \%$ ) to 19 (probability of 100\%). For unguaranteed loans, BNG Bank itself monitors not only the riskiness of the corporation, but also that of the specific project being financed. This variable may therefore provide additional information on top of corporation characteristics. Note that this variable is only available for unguaranteed loans.

- Maturity is the number of years in which the loan is due.

- Loan sum is the amount of money borrowed (the principle).

- Delay indicates the difference (in days) between the contracting and starting day (money transfer) of the loan arrangement. As the interest rate of immediate borrowing is higher than the return on a deposit for the delay period, this loss of interest is covered by an additional spread on the borrowing rate.

- Guaranteed is a dummy variable that equals 0 if the loan is unguaranteed and 1 if the loan is guaranteed.

Table 1 gives descriptive statistics concerning the interest spreads and the independent variables.

\subsection{Linking Housing Corporation Data with Loan Data}

Housing corporation specific variables are given on a yearly basis - they reveal the situation of the corporation at the end of a year. Data on corporation loans give information on the date of the loans. The question of how to combine yearly and daily data is somewhat arbitrary.

According to BNG Bank, several sources are used to obtain the most recent information about the housing corporation. ${ }^{11}$ For our main results, we therefore assume that the bank has the most up-to-date information. To check for robustness, we have repeated our analysis under the assumption that it takes a year to obtain this data, which would be the case should the bank rely solely on annual reports (see the sensitivity analysis, Sect. 7). Thus, we describe two scenarios:

- In the standard scenario, we link all loans in the first half of year $t$ to corporation characteristics in year $t-1$. Loans in the second half of year $t$ are linked to year $t$ itself.

- In the lagged scenario, we link all loans in the first half of year $t$ to corporation characteristics in year $t-2$. Loans in the second half of year $t$ are linked to year $t-1$.

\section{Results}

\subsection{Hypothesis 1}

Table 2 presents the estimated results of Eq. (4). Regression (1) gives the results for all loans, and Regressions (2)-(6) give the results per loan type.

\footnotetext{
11 Source: interview with the specialist for the social housing sector of BNG Bank.
} 


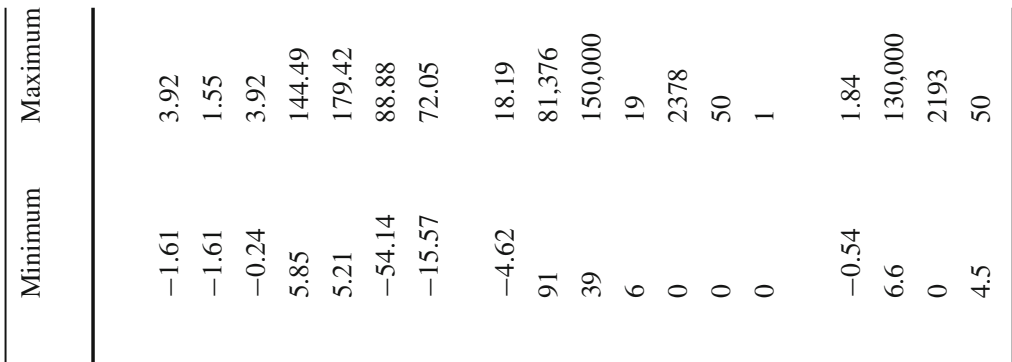

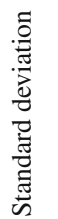

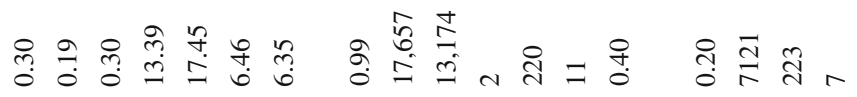

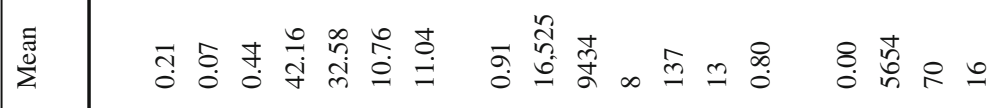

$$
\begin{aligned}
& \text { 믈 } \\
& \text { 离 } \\
& \text { z }
\end{aligned}
$$

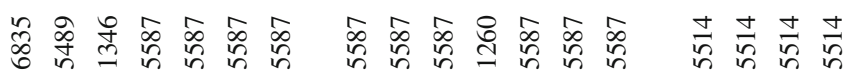

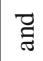

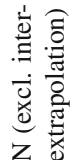

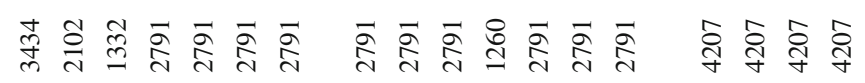

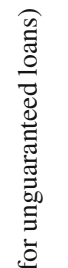

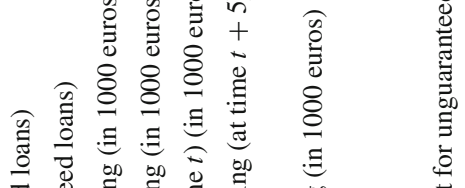

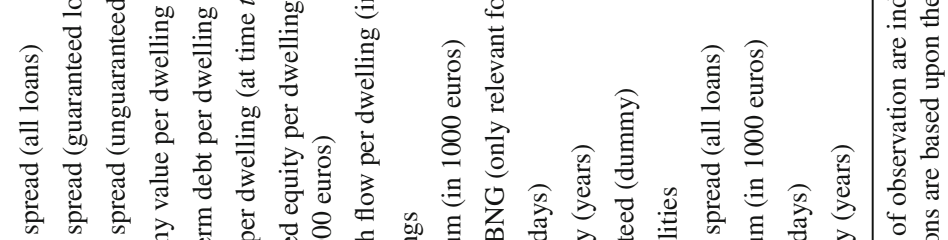

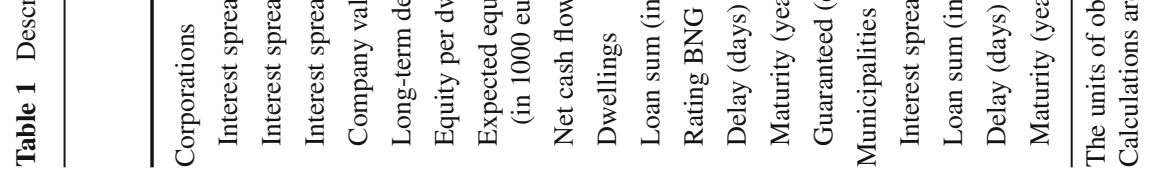




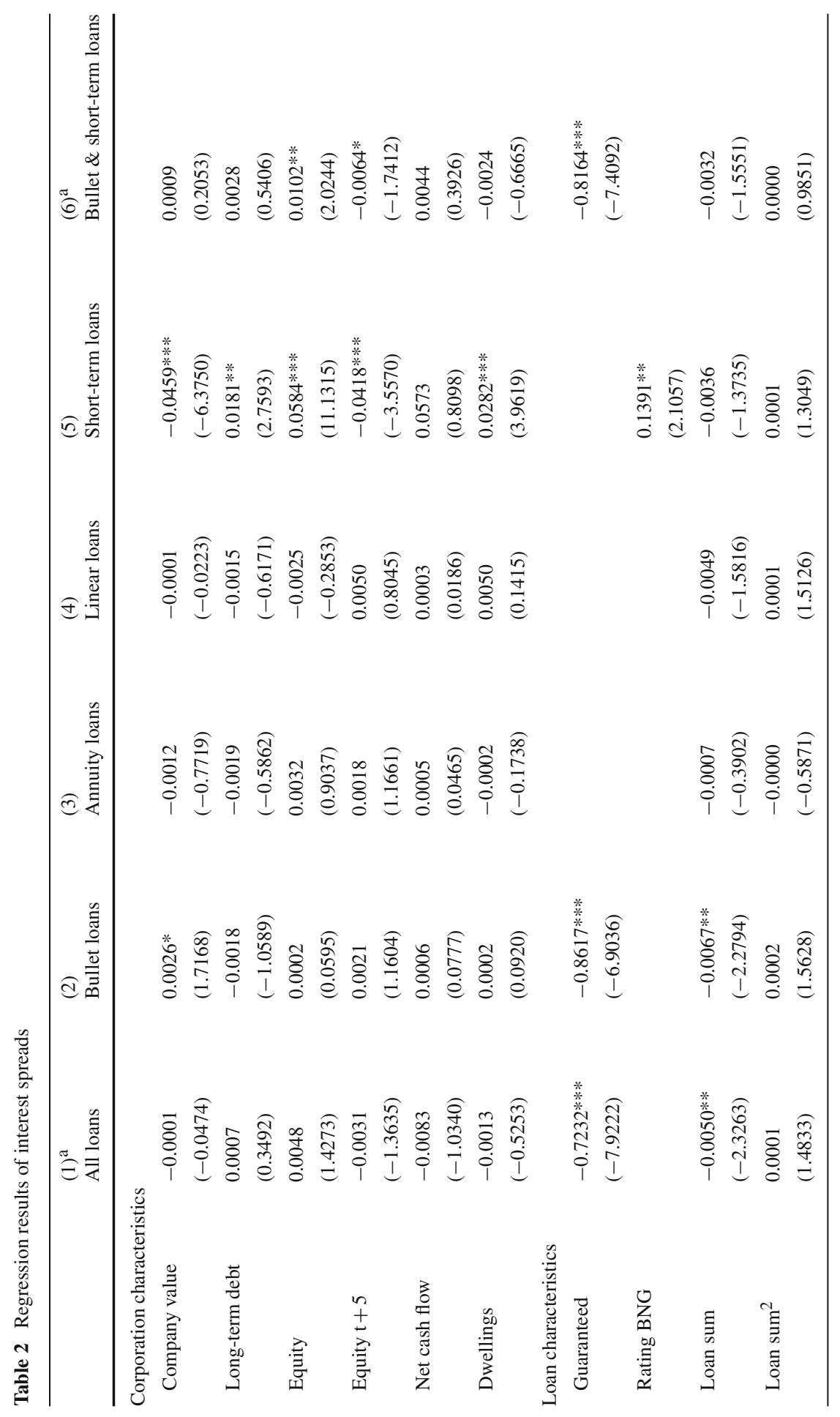




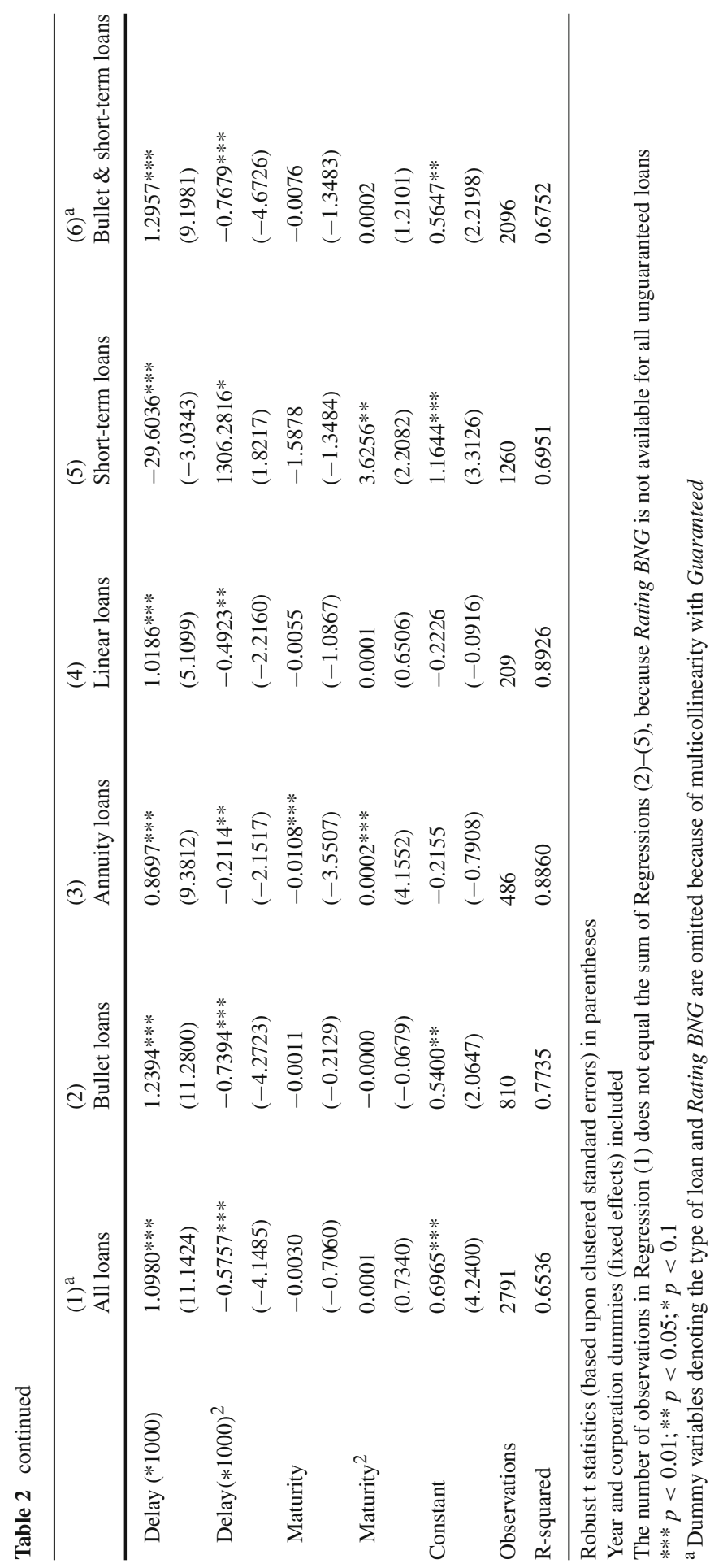


Regression (1) shows that the coefficient on guaranteed is negative and highly significant which confirms Hypothesis 1 . The coefficient is -0.7232 , which means that the bailout clause reduces the interest spread by around 72 basis points.

Note that in Regression (1), we have not included dummy variables for loan type (i.e., type of amortisation). This is because the variable 'short-term loan' suffers from multicollinearity with the variable guaranteed. Indeed, as noted, most unguaranteed loans are short-term loans. Therefore, we cannot completely isolate the effect of the bailout clause. It could be argued that the difference in spreads between guaranteed and unguaranteed loans is (partly) due to the difference in loan type.

However, when including loan type dummies in Regression (1), we find no significant difference in interest spread between different long-term loan types (i.e., the coefficients of dummies for bullet, annuity and linear loans are insignificant; details not shown). Thus the loan type does not seem to be influential.

Additionally, note that there are also three unguaranteed bullet loans (11 when including inter- and extrapolation; see Sect. 7). Regression (2), dealing with bullet loans only, indicates that the interest spread is about 86 basis points higher for unguaranteed loans.

One may also argue that bullet loans and short-term loans are essentially the same (as for both loan types the principal is paid back at maturity). The only difference is in fact the difference in maturity. Regression (6) shows the results for bullet and short-term loans together. The bailout clause remains significant, and the coefficient is increased to -0.8164 .

However, these regressions still fail to fully separate the effect of maturity on the interest spread (i.e. the term structure of the interest spread) from the effect of a bailout clause. ${ }^{12}$ Although in principle, there would be no reason to expect the interest spread to change with maturity (see Sect. 4), we need to ascertain this empirically. Figure 1 plots interest spreads against maturity and provides two separate linear regression lines (one for short-term loans and one for long-term loans). ${ }^{13}$ The figure only includes short-term and (long-term) bullet loans. Cleary, interest spreads are higher for shortterm (and thus unguaranteed) loans. Most importantly however, there appears to be no relationship between maturity and interest spreads for loans with a maturity of more than 2 years.

To deal with this issue more formally, we estimate a regression where we explain the interest spread by maturity and several polynomials of maturity. When including only long-term bullet loans (Regression 1 in Table 3), maturity does not have a significant impact. In Regression (2) we combine both short-term and (long-term) bullet loans, and add a dummy variable that equals 1 if maturity is longer than 2 years. The idea is that the relationship between maturity and interest spread should show a discontinuity

\footnotetext{
12 Although maturity and maturity ${ }^{2}$ are included in the regressions, this does not fully reveal the term structure of interest spreads.

13 Note that on the horizontal axis of the figure, total maturity is given. In practice however, interest rates are linked to the fixed interest period, which may be shorter than the total maturity of the loan (see also footnote 9). Repeating the analysis for the fixed interest period instead of the total maturity leads to the same conclusions however (results not shown).
} 


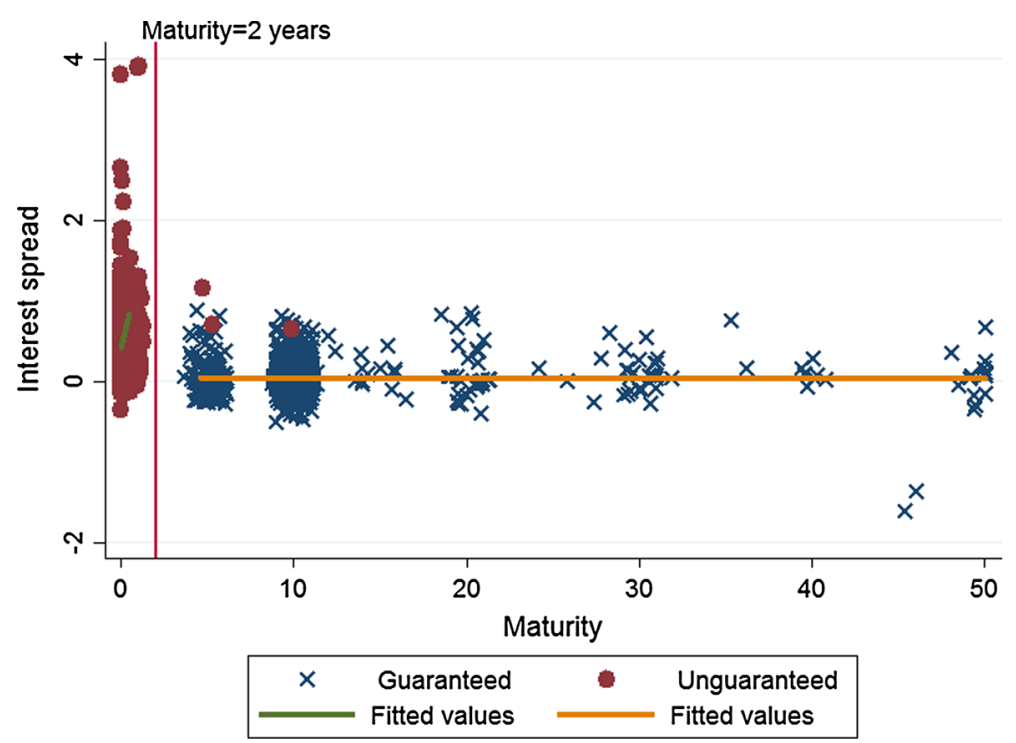

Fig. 1 Scatter plot and regression lines of interest spreads against maturity. Note We have used the jitter option in Stata to show the mass of the data

at a maturity of 2 years. ${ }^{14}$ According to Regression (2) of Table 3, maturity has a (mostly weak) significant impact on the interest spread, but so does the dummy. So, indeed, there appears to be a structural break. To get an idea of a potential term structure on interest rates, Fig. 2 plots the predicted interest spreads (based upon the regression coefficients in Table 3) against maturity. The line in Fig. 2a is based on Regression (1) (thus excluding short-term loans), the line in Fig. 2b is based on Regression (2) (including short-term loans). According to Fig. 2a, there is hardly any relationship between interest spreads and maturity. According to Fig. 2b, there is a sharp downfall in spreads after a maturity of 2 years. If maturity increases further, the term structure is almost flat. Only at very high levels of maturity the line fluctuates more, which is partly due to the observations at the bottom right. ${ }^{15}$

All in all, although the dataset does not allow for a perfect identification strategy, we conclude that we find substantial evidence that the guarantee scheme succeeds in lowering interest rates. Also, the no-bailout clause for unguaranteed loans appears to be credible.

To give an indication of the impact of the bailout clause, note that the total level of guaranteed corporation debt was 85.1 billion euro in 2014 (source: WSW 2015). According to Regression (1) in Table 2, without the bailout clause corporations would have to pay an additional $0.72 \%$ interest over this debt. This implies that the estimated benefits to society of the bailout would be around 610 mil-

\footnotetext{
14 This approach could be classified as a regression discontinuity design (Thistlethwaite and Campbell 1960; Lee and Lemieux 2010).

15 These might be outliers due to administrative mistakes, or because of specific circumstances concerning the loan or the borrowing corporation. The dataset does not allow us to find this out.
} 
Table 3 Regression results of interest spreads against maturity

\begin{tabular}{|c|c|c|}
\hline & $\begin{array}{l}\text { (1) } \\
\text { Bullet loans (long-term) }\end{array}$ & $\begin{array}{l}\text { (2) } \\
\text { Short-term and (long-term) bullet loans }\end{array}$ \\
\hline Maturity & $\begin{array}{l}0.0353 \\
(0.2323)\end{array}$ & $\begin{array}{l}0.2191 \\
(1.5702)\end{array}$ \\
\hline Maturity $^{2}$ & $\begin{array}{l}-0.0075 \\
(-0.4024)\end{array}$ & $\begin{array}{l}-0.0290 * \\
(-1.7077)\end{array}$ \\
\hline Maturity ${ }^{3}$ & $\begin{array}{l}0.0005 \\
(0.5577)\end{array}$ & $\begin{array}{l}0.0016^{*} \\
(1.8451)\end{array}$ \\
\hline Maturity ${ }^{4}$ & $\begin{array}{l}-0.00001 \\
(-0.6831)\end{array}$ & $\begin{array}{l}-0.00004 * \\
(-1.9509)\end{array}$ \\
\hline Maturity ${ }^{5}$ & $\begin{array}{l}1.28 \mathrm{e}-07 \\
(0.7761)\end{array}$ & $\begin{array}{l}2.99 \mathrm{e}-07 * * \\
(2.0218)\end{array}$ \\
\hline Dummy maturity $>2$ years & & $\begin{array}{l}-0.9124 * * \\
(-2.3903)\end{array}$ \\
\hline Constant & $\begin{array}{l}0.0431 \\
(0.1051)\end{array}$ & $\begin{array}{l}0.4314 * * * \\
(16.0886)\end{array}$ \\
\hline Observations & 978 & 2304 \\
\hline R-squared & 0.0314 & 0.3579 \\
\hline
\end{tabular}

Robust t statistics (based upon clustered standard errors) in parentheses

$* * * p<0.01$; ** $p<0.05$; * $p<0.1$

lion euro (85.1 billion*0.72\%) per year in reduced interest payments. ${ }^{16}$ Using the coefficient of Regression (6), the savings would be around 700 million euro (85.1 bln*0.82\%).

The direct costs of the bailout clause could be shown in the total loan sum on which corporations defaulted. Although we do not have this information directly, we do know the amount of reorganisation subsidies provided to corporations in order to restore their financial position. As noted in Sect. 2.2, from 31 December, 1990 until 2014, the CFV provided 1.5 billion euro in reorganisation subsidies (in 2014 euros). Note that there may also be secondary costs involved if, for example, the bailout clause led to operational inefficiency. It is not possible to measure this, however, as there are no corporations that do not operate under the bailout clause. But we do know that these costs would have to be substantial in order to outweigh the benefits of the bailout clause. Indeed, if we compare the estimate of yearly benefits (610 million euro) with the direct costs of about 63 million euro (1.5

\footnotetext{
16 Note that these are gains to society. Indeed, the bank would be indifferent between making a risk-free loan at the risk-free rate and a risky loan at a higher rate. Corporations would of course prefer the former. Therefore, the reduction in interest payments is a pure gain to the social housing sector, and because corporations have the obligation to use all of their resources for social housing, these are gains to society.
} 

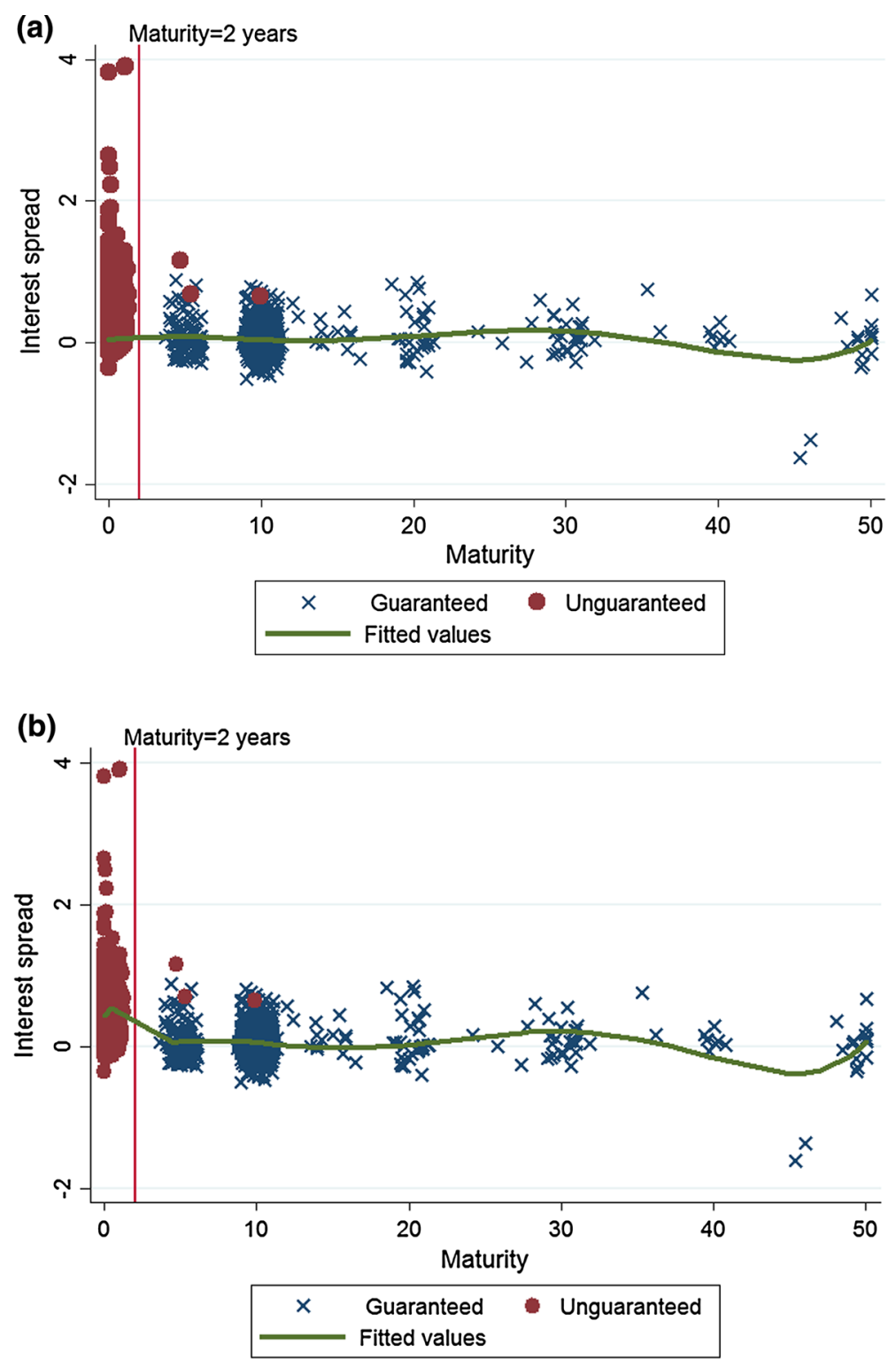

Fig. 2 Estimated term structure of interest spreads. a line based on Regression (1) in Table 3. b line based on Regression (2) in Table 3. Note We have used the jitter option in Stata to show the mass of the data

billion/24 years), the indirect costs of the bailout clause would have to amount to nearly 550 million euro per year for the bailout clause to be considered undesirable. $^{17}$

\footnotetext{
17 Note that while the bailout clause also leads to monitoring costs for (the CFV and) the WSW, at the same time it relieves BNG Bank from monitoring. Although it is uncertain who would have lower monitoring
} 


\subsection{Hypothesis 2}

According to Regressions (2)-(4) in Table 2, corporation characteristics have no influence on the interest spreads for guaranteed loans. This is in line with Hypothesis 2; BNG Bank does not appear to monitor corporations when providing guaranteed loans. One might note, however, that these regressions may suffer from overestimated standard errors due to multicollinearity among regressors. Indeed, the regressors all measure the financial position of corporations in some way. However, the Variance Inflation Factors (VIF) lie well below 10, so multicollinearity does not seem troublesome. Also, removing variables (and for example keeping only long-term debt in the regression) does not alter our conclusions (results not shown). Additionally, one may note that the variation among corporations could be captured by the corporation dummies (fixed effects). However, removing the corporation dummies does not render the corporation characteristics significant.

Regression (5) shows that, in contrast to guaranteed loans, housing corporation characteristics are highly relevant for short-term (and thus unguaranteed) loans: higher company value, lower long-term debt and higher expected equity all lead to a reduction of interest spreads. This is also in line with Hypothesis 2. The main exception, however, is the significant positive effect of equity on the interest spread. This appears to be counterintuitive, as higher equity implies a more favourable financial position (CFV 2012), which in turn should decrease rather than increase interest rates. One may argue that corporations with high equity become lax in their search for low funding costs because of their favourable prospects. ${ }^{18}$ We note however that the results from Regression (5) are not robust among all specifications. For example, the coefficient on equity becomes insignificant once all other corporation characteristics are excluded. Also, the other variables lose significance in some cases (results not shown). This means that although it is likely that monitoring is present, the evidence is not fully robust.

Another confirmation of Hypothesis 2 is the fact that the risk rating BNG Bank allocates to each unguaranteed loan positively influences the interest spread.

Finally, it appears that the scale of the housing corporation (i.e., the number of dwellings) is only relevant for short-term (unguaranteed) loans. If the number of dwellings increases, the interest spread increases as well. This is rather surprising as we would have expected a negative relationship (see Sect. 3.2). It could be that for larger housing corporations, the stakes are higher, so that monitoring is conducted more strictly.

\subsection{Hypothesis 3}

According to Table 1, even guaranteed corporation loans show a positive interest spread of seven basis points on average, while for municipalities, the average spread

Footnote 17 continued

costs, we presume that the difference between the two is not large enough to effect the desirability of the bailout clause.

18 If this would be the case, one may be surprised that we do not find an effect of equity on the interest spread for guaranteed loans. However, it may be more easy to bargain on guaranteed loans, because for these loans, BNG Bank publicly provides a target price (see Sect. 5.2). 
Table 4 Regression results of interest spreads: comparison of corporations and municipalities

\begin{tabular}{|c|c|c|c|c|}
\hline & $\begin{array}{l}\text { (1) } \\
\text { All guaranteed loans }\end{array}$ & $\begin{array}{l}\text { (2) } \\
\text { Bullet loans }\end{array}$ & $\begin{array}{l}\text { (3) } \\
\text { Annuity loans }\end{array}$ & $\begin{array}{l}(4) \\
\text { Linear loans }\end{array}$ \\
\hline Loan sum & $\begin{array}{l}-0.0031 * * * \\
(-9.0537)\end{array}$ & $\begin{array}{l}-0.0026^{* * * *} \\
(-3.9833)\end{array}$ & $\begin{array}{l}-0.0026^{* *} \\
(-2.5247)\end{array}$ & $\begin{array}{l}-0.0032^{* * *} \\
(-5.6406)\end{array}$ \\
\hline Loan sum ${ }^{2}$ & $\begin{array}{l}0.0000 * * * \\
(5.5420)\end{array}$ & $\begin{array}{l}0.0000^{* *} \\
(2.2311)\end{array}$ & $\begin{array}{l}0.0000 \\
(1.2710)\end{array}$ & $\begin{array}{l}0.0000^{* *} \\
(2.5494)\end{array}$ \\
\hline Delay(*1000) & $\begin{array}{l}0.8639 * * * \\
(26.8314)\end{array}$ & $\begin{array}{l}1.1421 * * * \\
(17.1171)\end{array}$ & $\begin{array}{l}0.8728 * * * \\
(16.1885)\end{array}$ & $\begin{array}{l}0.8687 * * * \\
(19.7033)\end{array}$ \\
\hline Delay $(* 1000)^{2}$ & $\begin{array}{l}-0.1655^{* * *} \\
(-5.5507)\end{array}$ & $\begin{array}{l}-0.6228 * * * \\
(-7.2900)\end{array}$ & $\begin{array}{l}-0.1903 * * * \\
(-3.6434)\end{array}$ & $\begin{array}{l}-0.1288^{* * *} \\
(-3.7067)\end{array}$ \\
\hline Maturity & $\begin{array}{l}-0.0054 * * * \\
(-6.0304)\end{array}$ & $\begin{array}{l}0.0003 \\
(0.1002)\end{array}$ & $\begin{array}{l}-0.0087 * * * \\
(-4.8993)\end{array}$ & $\begin{array}{l}-0.0076^{* * *} \\
(-4.8429)\end{array}$ \\
\hline Maturity $^{2}$ & $\begin{array}{l}0.0001 * * * \\
(5.3575)\end{array}$ & $\begin{array}{l}-0.0000 \\
(-0.2108)\end{array}$ & $\begin{array}{l}0.0002 * * * \\
(5.8701)\end{array}$ & $\begin{array}{l}0.0002 * * * \\
(4.3455)\end{array}$ \\
\hline Linear loan & $\begin{array}{l}-0.0177 * * * \\
(-3.0520)\end{array}$ & & & \\
\hline Bullet loan & $\begin{array}{l}-0.0282 * * * \\
(-4.1534)\end{array}$ & & & \\
\hline Corporation dummy & $\begin{array}{l}0.0035 \\
(0.7211)\end{array}$ & $\begin{array}{l}0.0045 \\
(0.6329)\end{array}$ & $\begin{array}{l}-0.0087 \\
(-1.0402)\end{array}$ & $\begin{array}{l}0.0075 \\
(0.8203)\end{array}$ \\
\hline Constant & $\begin{array}{l}-0.0496 * * * \\
(-3.0204)\end{array}$ & $\begin{array}{l}0.1531 \\
(1.4161)\end{array}$ & $\begin{array}{l}0.0115 \\
(0.3199)\end{array}$ & $\begin{array}{l}0.0158 \\
(1.0450)\end{array}$ \\
\hline Observations & 6324 & 1454 & 1136 & 3734 \\
\hline R-squared & 0.6703 & 0.5984 & 0.6675 & 0.7158 \\
\hline
\end{tabular}

Robust $\mathrm{t}$ statistics in parentheses

Year dummies included

$* * * p<0.01 ; * * p<0.05 ; * p<0.1$

is just zero. Equation (3b) shows that this may be due to non-recoverable costs (c). As noted, non-recoverable costs are probably more relevant for housing corporations than for municipalities, and therefore, interest spreads on guaranteed housing corporation loans may exceed interest spreads on municipality loans. We can compare interest rates of both groups of organisations by estimating Eq. (5). The results in Table 4 indicate that there is no significant difference in interest rates between corporations and municipalities as the corporation dummy is insignificant in all regressions. Therefore, we reject Hypothesis 3 and conclude that non-recoverable costs are not relevant. This suggests that the bailout clause for housing corporations (securing individual loans) succeeds in matching the one for municipalities (which entirely protects municipalities from defaulting). Both clauses seem equally credible.

Still, it may be puzzling to see that interest rates for guaranteed housing corporation loans exceed their risk-free reference rates. As noted in Sect. 3.1, this positive interest spread might be due to BNG Bank succeeding in obtaining positive com- 
mercial margins. A commercial margin may be the result of bargaining practices. Indeed, Allers and van Ommeren (2016) present evidence suggesting that intermunicipal organisations can reduce interest rates on loans from BNG Bank by bargaining more effectively. It could also be the case that BNG Bank has lower funding costs than other banks because of implicit subsidies (see Sect. 2.1). Further research is needed to solve this issue.

\section{Sensitivity Analysis}

We test the robustness of our results from Hypotheses 1 and 2 in six ways. This section briefly describes the results, for a more extensive discussion, see the online Appendix.

Firstly, we define an interest spread in relative (rather than absolute) terms. We find that the coefficient on guaranteed now differs significantly between Regressions (1) and (2) (see Table 5). Therefore, it seems that an interest premium is charged in basis points, rather than a percentage. This makes the absolute spread more appropriate.

Secondly, we include loans for which only inter- or extrapolated reference rates are available. For example, the reference rate of a bullet loan with a maturity of 8 years can be found by interpolating the reference rates for a 5-year loan and a 10-year loan. This increases the total number of observations from 2791 (Table 2) to 5587 (Table 5). The bailout effect is reduced somewhat (from -0.72 in Table 2 to -0.66 in Table 6) with estimated interest savings of about 560 million euro $(85.1 \mathrm{bln} * 0.66 \%)$. Additionally, the results still indicate that corporation characteristics are only relevant for unguaranteed loans.

Thirdly, the results for non-clustered (but robust) standard errors are similar to the main results in Table 2.

Fourthly, we use the lagged scenario (instead of the standard scenario, see Sect. 5.4). For guaranteed loans, results are similar to Table 2. However, for unguaranteed loans, most corporation characteristics lose significance (details can be found in the online Appendix). It appears likely therefore that BNG Bank is aware of a corporation's circumstances before its financial data become publicly available in its annual report.

Fifthly, we remove all loans with a maturity up to 1 month. The number of observations falls sharply, but the coefficient on guaranteed remains similar to the main results.

Sixthly, we investigate whether there is a difference in monitoring in the pre- and post-crisis period, i.e., before or after 16 September 2008. According to Zipfel and Zimmer (2013), there is reason to believe that since the economic crisis, suppliers of capital may be more aware of the riskiness of, for example, subnational governments. Note that nearly all the short-term loans we study were made after September 2008 whereas our dataset contains guaranteed loans for the pre-crisis period as well. It may be the case that since the crisis, corporation characteristics are also relevant for guaranteed loans. To test this, we include interaction terms between the corporation characteristics and a crisis dummy which equals 1 for all loans made from 16 September 2008 onwards and zero otherwise. Hardly any significant results appear so that we find no evidence of extra monitoring activities since the crisis.

We also test the robustness of Hypothesis 3 by including inter- and extrapolated loans. Table 6 shows that the corporation dummy becomes significant in Regression 


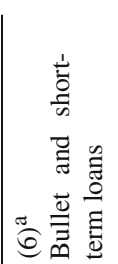

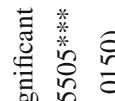

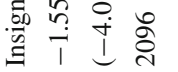

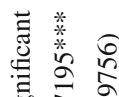

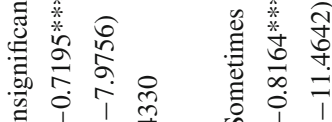

छ̊

节莡

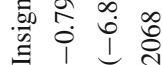

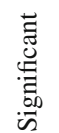

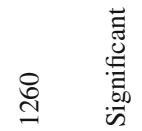

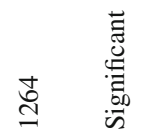

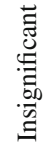

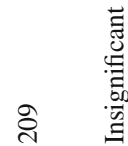

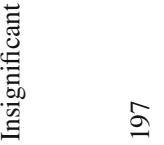

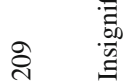

ले

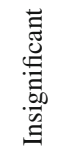

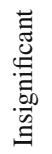

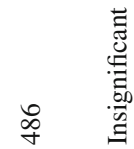

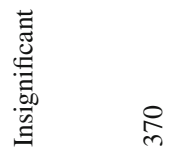

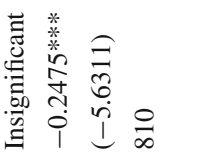

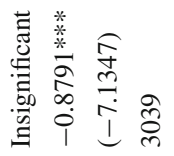

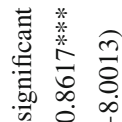

焉

$\stackrel{\substack{n \\ \frac{\pi}{2}}}{\frac{\pi}{*}}$

高节离

$\simeq$

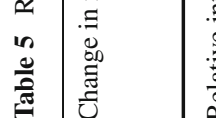

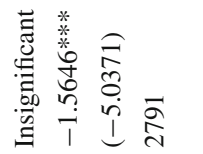

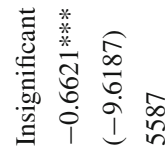

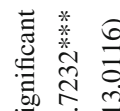

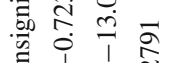

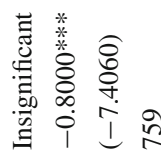
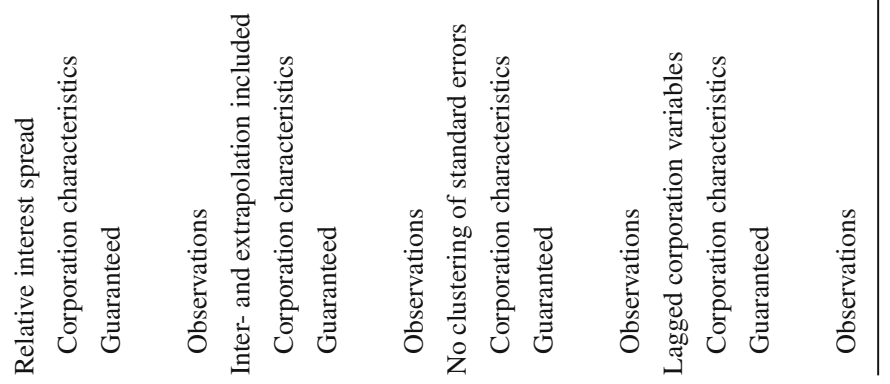

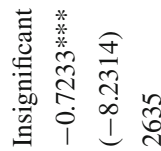




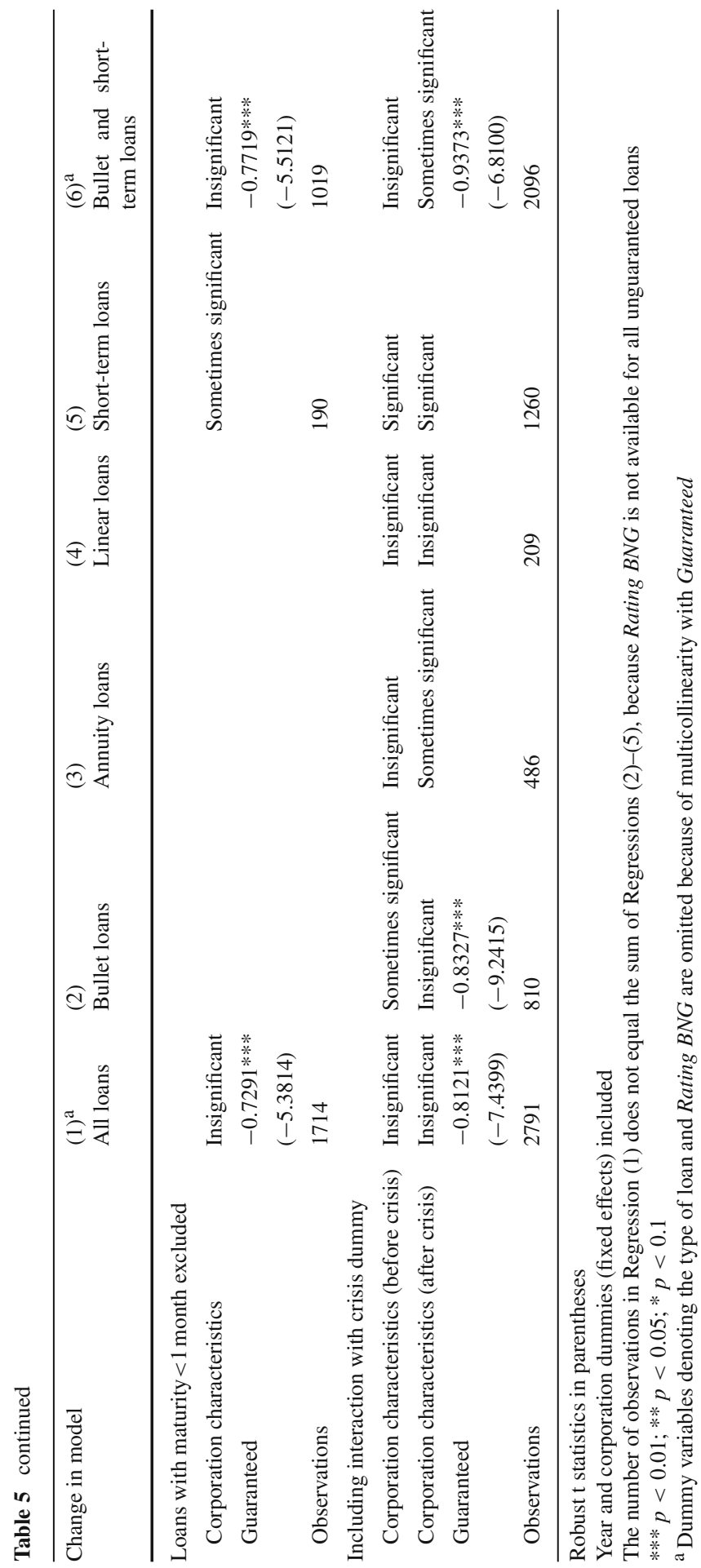


Table 6 Regression results: comparison of corporations and municipalities (inter- and extrapolation included)

\begin{tabular}{lllll}
\hline & $(1)$ & $(2)$ & $(3)$ & $(4)$ \\
& All guaranteed loans & Bullet loans & Annuity loans & Linear loans \\
\hline Corporation dummy & $0.0130^{* *}$ & 0.0083 & -0.0088 & 0.0074 \\
& $(1.9843)$ & $(0.8398)$ & $(-0.4574)$ & $(0.7189)$ \\
Constant & $0.0566^{* * *}$ & $-0.1138^{* * *}$ & 0.0118 & $-0.0470^{* *}$ \\
& $(2.8517)$ & $(-3.2257)$ & $(0.1847)$ & $(-2.0981)$ \\
Observations & 11,062 & 4746 & 1992 & 4324 \\
R-squared & 0.2974 & 0.2898 & 0.2213 & 0.6391 \\
\hline
\end{tabular}

Robust $\mathrm{t}$ statistics in parentheses

Loan characteristics and year dummies included

*** $p<0.01$;** $p<0.05 ; * p<0.1$

(1), but the coefficient is very small (about one basis point) and loses significance again in the other regressions. ${ }^{19}$ Therefore, we conclude that we fail to find robust evidence of non-recoverable costs.

\section{Conclusion}

The Dutch (semi-)public sector is characterized by its bailout clauses. Though shortterm loans to housing corporations are not guaranteed, most long-term corporation loans are explicitly guaranteed. The bailout clause for corporations consists of three levels: the first two relying on mutual solidarity, and the third on governmental support. In spite of what one would expect based on the literature, only rarely has the guarantee scheme been called upon. Recently, however, incidents involving the housing corporation sector have brought back the plea to rein in or even abolish the bailout clause.

In this paper we have compared interest spreads (i.e., the difference between the actual interest rate paid and a risk-free reference rate) of guaranteed and unguaranteed corporation loans provided by BNG Bank, the market leader in this sector. While controlling for other relevant factors we have found that the guarantee scheme lowers interest rates by about 72 basis points. This yields yearly benefits to the social housing sector of around 610 million euro in reduced interest payments. Comparing this with the bailout payments provided to rescue corporations ( 1.5 billion euro in 24 years), it appears likely that the bailout clause has had a positive net benefit. This means that the bailout clause would only be undesirable if it led to very high indirect costs such as, for example, loss of efficiency.

The relevance of the bailout clause is again confirmed by our finding that a housing corporation's financial position (or riskiness) influences interest spreads for unguaranteed loans only. This indicates that, in our research period, BNG Bank did not monitor

\footnotetext{
19 Significance is also lost when including Delay ${ }^{3}$ (which is significant) in Regression (1) of Table 6 (details not shown).
} 
corporations when providing guaranteed loans, but relied on the credibility of the bailout clause and the assessment of the supervisory authorities (CFV and WSW). For unguaranteed loans, however, BNG Bank does monitor the riskiness of corporations as well as that of the project being financed.

Finally, we find that interest rates on guaranteed housing corporation loans exceed their risk-free reference rates. In theory, this may imply that the creditor charges a premium for non-recoverable costs in case of default, despite the guarantee scheme. This would mean that guaranteed loans are not completely risk-free. However, we argue that non-recoverable costs are not relevant for housing corporations. If they were, we would expect corporations to pay higher interest rates than municipalities as non-recoverable costs would be higher for corporations than for municipalities. This is because BNG Bank would be involved in the bailout process if a corporation defaults, whereas for municipalities, the bailout would work automatically. However, we find no structural significant difference between the two. The guarantee scheme for housing corporations (securing individual loans) reduces interest rates to the same extent as the one for municipalities (whose entire financial position is secured). Positive interest spreads probably reflect a commercial margin.

We emphasize that we do not argue that bailout clauses are desirable under all circumstances, but rather that they are not undesirable per se. Further study is needed to investigate whether our findings also hold for other bailout clauses.

Acknowledgements The authors would like to thank Marloes van Gelder for providing excellent research assistance. We also thank René Goorden, Hans Leenaars, Maarten Allers, Paul Elhorst, Rob Alessie, Valentino Colombo, participants of the 71st Annual Congress of the IIPF, Dublin, 2015 and two anonymous reviewers, for providing useful comments to earlier versions of this paper. Finally, we thank the Central Public Housing Fund (Centraal Fonds Volkshuisvesting, CFV) and BNG Bank for providing data.

Open Access This article is distributed under the terms of the Creative Commons Attribution 4.0 International License (http://creativecommons.org/licenses/by/4.0/), which permits unrestricted use, distribution, and reproduction in any medium, provided you give appropriate credit to the original author(s) and the source, provide a link to the Creative Commons license, and indicate if changes were made.

\section{References}

Allers, M. A. (2015). The Dutch local government bailout puzzle. Public Administration, 93, 451-470.

Allers, M. A., \& van Ommeren, B. J. F. (2016). Intermunicipal cooperation, municipal amalgamation and the price of credit. Local Government Studies, 42, 717-738.

Birry, A., Hauville, C., Roy, D., \& Ashworth, S. (2013). Three Dutch financial service groups ratings lowered following similar action on The Netherlands. Delaware: Standard \& Poor's Financial Services LLC.

Booth, L., Georgopoulos, G., \& Hejazi, W. (2007). What drives provincial-Canada yield spreads? Canadian Journal of Economics, 40, 1008-1032.

CFV. (2012). Toelichting CFV 2012. Corporatie in Perspectief. Baarn: Centraal Fonds Volkshuisvesting.

CFV. (2015). Vizier. Jaarverslag 2014. Baarn: Centraal Fonds Volkshuisvesting.

de Jong, R. (2013). De Balans Verstoord. Een rapport over de corporatiesector ten behoeve van de Parlementaire Enquête Woningcorporaties. Rapport in opdracht van Aedes vereniging van woningcorporaties. Den Haag.

Feld, L.P., Kalb, A., Moessinger, M., \& Osterloh, S. (2013). Sovereign bond markets reactions to fiscal rules and no-bailout clauses-The Swiss experience. ZEW discussion paper 13-034.

Finance Ideas. (2011). Toelichting Resultaten Corporatie Survey 2011 Editie I. Utrecht: Finance Ideas.

Goodspeed, T. J. (2002). Bailouts in a federation. International Tax and Public Finance, 9, 409-421.

Hendriks, P. (2013). Staatsgarantie ja of nee? Aedes Magazine 07-07-2013. 
Heppke-Falk, K. H., \& Wolff, G. B. (2008). Moral hazard and bail-out in fiscal federations: Evidence for the German Länder. Kyklos, 61, 425-446.

Kornai, J., Maskin, E., \& Roland, G. (2003). Understanding the soft budget constraint. Journal of Economic Literature, 41, 1095-1136.

Küttel, D., \& Kugler, P. (2002). Explaining yield spreads of Swiss canton bonds: An empirical investigation. Financial Markets and Portfolio Management, 16, 208-218.

Landon, S., \& Smith, C. E. (2007). Government debt spillovers in a monetary union. North American Journal of Economics and Finance, 18, 135-154.

Lee, D. S., \& Lemieux, T. (2010). Regression discontinuity designs in economics. Journal of Economic Literature, 48, 281-355.

Lemmen, J. (1999). Managing government default risk in federal states. London School of Economics, Economic \& Social Research Council, Financial Markets Group, Special Paper, 116.

Ministry of the Interior and Kingdom Relations. (2016). Brief aan de Voorzitter van de Tweede Kamer der Staten-Generaal. Kenmerk: 2016-0000279934.

Moulton, B. R. (1990). An illustration of pitfall in estimating the effects of aggregate variables on micro units. The Review of Economics and Statistics, 72, 334-338.

Nichols, A., \& Schaffer, M. E. (2007). Clustered errors in stata. United Kingdom Stata Users' Group Meetings 2007, 07, Stata Users Group.

Noss, J., \& Sowerbutts, R. (2012). The implicit subsidy of banks. London: Bank of England, Financial Stability Paper, 15.

Plekhanov, A., \& Singh, R. J. (2007). How should subnational government borrowing be regulated? Some cross-country empirical evidence. IMF Staff Papers, 53, 426-452.

Rodden, J. (2006). Hamilton's paradox. The promise and peril of fiscal federalism. Cambridge: Cambridge University Press.

Rogers, W. H. (1993). Regression standard errors in clustered samples. Stata Technical Bulletin, 13, 19-23.

Schuknecht, L., von Hagen, J., \& Wolswijk, G. (2009). Government risk premiums in the bond market: EMU and Canada. European Journal of Political Economy, 25, 371-384.

Schulz, A., \& Wolff, G. B. (2009). The German sub-national government bond market: Structure, determinants of yield spreads and Berlin's forgone bail-out. Jahrbücher für Nationalökonomie und Statistik (Journal of Economics and Statistics), 229, 61-83.

Thistlethwaite, D. L., \& Campbell, D. T. (1960). Regression-discontinuity analysis: An alternative to the ex post facto experiment. Journal of Educational Psychology, 51, 309-317.

van der Schaar, J. (2006). Verzelfstandiging van woningcorporaties. In Raad voor de Volksgezondheid en Zorg. Dossier management van vastgoed in de zorgsector (pp. 91-130). Zoetermeer: Raad voor de Volksgezondheid en Zorg.

van Hecke, A., Smedts, J., \& Heremans, D. (2012). De rente op regionale schulduitgiften: determinanten van regionale risicopremies en kredietratings. Katholieke Universiteit Leuven, Vives beleidspaper, 15.

Whitehead, C., \& Scanlon, K. (2007). Social housing in Europe. London School of Economics and Political Science

WSW. (2009). Cijfermatig Perspectief Woningcorporaties. Periode 2007-2010. Hilversum: Waarborgfonds Sociale Woningbouw.

WSW. (2014). Visie WSW op aflossingsplicht leningen Daeb aan niet-Daeb. Hilversum: Waarborgfonds Sociale Woningbouw.

WSW. (2015). Hoeder van de borg. Jaarverslag 2014. Liquiditeitsprognose 2015-2019. Hilversum: Waarborgfonds Sociale Woningbouw.

Zipfel, F., \& Zimmer, J. (2013). Länder bonds: What drives the spreads between federal bonds and Länder bonds? Deutsche Bank Research, Current Issues. 